\title{
Poverty Reduction Model through Empowerment People's Economy According to Islamic Perspectives (Study on Islamic Village in Sikka-Flores District)
}

\author{
Rita Yunus ${ }^{1}$, Yosefina Andia Dekrita ${ }^{2}$, Muhammad Yamin ${ }^{3}$ and Andi Batary Citta ${ }^{4}$ \\ ${ }^{1}$ Tadulako University Palu, Indonesia, e-mail: rytha plw@yahoo.com \\ ${ }^{2}$ Nusa Nipa University Maumere, Indonesia, e-mail: andia@yahoo.com \\ ${ }^{3}$ IAIN Bone, Indonesia, e-mail: maipal@yahoo.com \\ ${ }^{4}$ STIM Lasharan Jaya Makassar, Indonesia, e-mail: citta2585@gmail.com
}

\begin{abstract}
Poverty is a phenomenon that is so easy to find everywhere both in the village and in the city, including in the Islamic village, SIKKA Regency, East Nusa Tenggara Province. The worrisome economic situation of the Islamic settlements in SIKKA District is not to be mourned, but to find a solution. Therefore, to get out of the crush of the economy, a big and persistent struggle is needed from every component of the people, starting from the policies of the authorities which favor the economic equality to the efforts of the people themselves. Islam has taught its followers to try to get a good life in the world and in the hereafter in order to achieve inner and outer prosperity. Therefore, it is not excessive if the religion of Islam can also be said to be a religion of empowerment, which seeks to empower its adherents to live a balanced life between worldly and spiritual needs. This research is focused on the description of the Islamic perspective economic empowerment model in SIKKA Islamic village to alleviate poverty. The type of research used is qualitative research with a descriptive approach. This study produced several models of poverty alleviation through economic empowerment according to Islamic perspectives, namely: Mosque-Based Empowerment Model with Establishment of BAITUL MAAL WAT TAMWIL (BMT) and Family Empowerment Post Program based on Mosques and Mosque Micro Loan Program Model (PMM).
\end{abstract}

Keywords: Poverty, economic empowerment, Islamic perspective

\section{Introduction}

One of the problems faced by the Indonesian government / country is poverty, poverty is a phenomenon that is so easy to find everywhere. Both in the village and in the city. Behind the grandeur of skyscrapers in Jakarta, for example, it is not too difficult for us to find shabby houses lined up along the banks of the river, or beggars who roam the crossroads. Admittedly, capitalism has indeed failed to solve the problem of poverty. The goal can be resolved, but what happens actually creates poverty.

Fundamental factors that cause poverty in Indonesia include human resources, natural resources, systems, and also cannot be separated from the figure of the leader, so that the dimensions are closely related to each other. The government sees that poverty is a very important social problem to be reduced and even eliminated in people's lives. If there is no genuine effort to alleviate it, then a nation or state will experience backwardness. Under development in physical development, development of human resources and economic development will cause the country to be controlled by other more advanced countries.

During the leadership of President SUSILO BAMBANG YUDOYONO and JOKO WIDODO, many efforts have been made to alleviate poverty with the aim of protecting families and groups of the poor through fulfilling their basic needs and empowering them to have the ability to do business and prevent new poverty, such as BLT (Direct Cash Assistance), KUR (People's Business Credit), development of UMKM, PNPM, Family Hope Program (PKH), provision of Prosperous Family Cards (KKS), improving poor rice distribution policies, providing health services for the underprivileged through the Prosperous Indonesia Card ( KIS), and there are many other programs. The poverty alleviation programs above have not been able to alleviate the Indonesian people from 
the depths of poverty which increasingly torture and persecute. This situation should be a selfevaluation for the government to continue to plan and take a policy that can bring Indonesia out of poverty.

The attention of the Islamic Religion to the problem of poverty is very large. In the word al-Qur'an the poor are mentioned up to 25 times, while FAQIR and FUQORO are up to 14 times (Muhammad Abdul BAQI'). Allah SWT says, "give food to those who are FAQIR" (QS. AL-Hajj, 22: 8). According to Yusuf Al-QARDAWI the negative consequences of poverty can damage the AQIDAH, morals and the broken of families, communities and the state.

In Islam there are two schools in explaining about who is actually called poor. First, the HANAFI and Maliki schools of opinion that are poor are "people who have nothing too." Secondly, the HAMBALI and SYAFI'I schools which claim to be poor are "people who have one-half of their needs or more but not enough". In our lives, the word poor is usually used as compound words with FAQIR, so that it becomes a poor FAQIR which means more or less the same.

Islam has taught its followers to try to get a good life in the world and in the hereafter in order to achieve inner and outer prosperity. Therefore, it is not excessive if the religion of Islam can also be said to be a religion of empowerment, which seeks to empower its followers to live a balanced life between worldly and spiritual needs. To get it, there needs to be empowerment in line with the Islamic paradigm itself as a movement or change religion, even as a liberating force, especially from underdevelopment and economic oppression.

SIKKA Regency is one of the Regencies of East Nusa Tenggara Province which is on Flores Island with the majority of its population being Catholic. But quite a lot of the population are Muslim, and in general they settle in the coastal areas of the sea. One of the Islamic villages that the writer exemplified and the most exotic in SIKKA Regency was WURING Village.

WURING Village (kampong Islam) is a BAJO tribe whose origin was from Sulawesi because of its journey, then arrived in MAUMERE and settled to build a village. BAJO people always choose a place to live that is not far from sea water, because almost all of their lives depend on sea products. Not far from the city of MAUMERE in the seaside area they live. There was once a devastating natural disaster in the form of a tsunami and devastated the devastation of MAUMERE including the WURING village because of the location of his residence which is by the sea. Because after the natural disaster, the government had moved the entire village to areas far from the sea and even placed in hilly areas. But what happens if their lives are separated from the source of life, they cannot live well and choose to return to their old village by the sea. Simple stage houses decorated with boats or small canoes in front of their homes. The yard of the house is in the form of clear blue sea water to green and in it swim beautiful fish. Because this village is a BAJO tribe, almost $99 \%$ of them embrace Islam. When viewed from the perspective of conventional economics it can be ascertained that residents of the village of WURING belong to the category of the poor. According to the HANAFI and Maliki schools, those who argue that poverty is "a person who has nothing too" and furthermore the HAMBALI and SHAFI'I schools which claim that poverty is "people who have one-half of their needs or more but not enough", then this WURING village also included in the category of poor people.

One of the flagship programs of SIKKA Regency is the marine and fisheries sector, which is also the main livelihood of the Islamic village community. This means that the attention of the District Government towards this sector will be prioritized. which will have an impact on the welfare of the population, but the phenomenon that appears to date if we take pictures of people's lives in the SIKKA District Islamic Village, is still very far from expectations. Therefore, it is necessary to empower efforts to be able to alleviate poverty in this area from an Islamic perspective, because according to the Islamic perspective, the Qur'an views that poverty is a social problem that must be alleviated, even dangerous diseases that must be treated.

The worrisome economic situation of the Islamic settlements in SIKKA District is not to be mourned, but to find a solution. Therefore, to get out of the crush of the economy, a big and persistent struggle 
is needed from every component of the people, starting from the policies of the authorities which favor the economic equality to the efforts of the people themselves. Every Muslim person is challenged to be harder in work, entrepreneurship, fairer in working together, communicative in action, more skillful in facilitating the network, and more professional in managing the real economic potentials and strengths of the people. Therefore, in addition to mastery of life skill or life skills, entrepreneurial skills, which are more real and urgent are needed for the development and empowerment of the people's economy and giving people the opportunity to get down (small people). However, it is very unfortunate that the empowerment of people's economy and the opportunity to be given less attention, economic development and empowerment have only been enjoyed by the upper middle class (bourgeois-conglomerates). As a result, economic disparities are increasingly apparent. Based on the above facts, currently a strategy and method of equitable economic empowerment is needed that can be enjoyed by the lower economy (poor people).

Therefore, this paper will discuss how the poverty alleviation model and empowerment of the poor and poor are offered by the Qur'an to improve the welfare of the population of the Islamic village in SIKKA Regency economically.

Understanding Poverty According to Islam. According to language, poor comes from the Arabic language which actually expresses profound poverty. Allah SWT. use that term in His word:

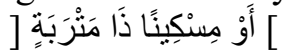

"... or poor people who are very poor" (Surah al- BALAD [90]: 16)

The word fakir, which comes from Arabic: al-FAQRU, means to need. Allah SWT. said:

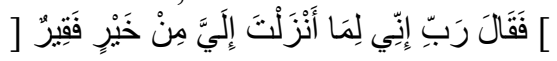

"... then he prayed," Yes Rabbi, actually I really need a good that you have sent me down" (Surah alQASAS [28]: 24).

In a more definitive sense, SHAIKH AN-NABHANI categorizes those who have property (money) but does not meet the expenditure needs of the poor. Meanwhile, the poor are people who do not have property (money), but do not have income. (NIDZAMUL IQTISHADI FIL ISLAM, p.236, DARUL UMMAH - Beirut). This category differentiation is right to explain the meaning of two MUSTAHIQ zakat posts, namely al-FUQARA (people FAQIR) and AL-MASAKIIN (poor people), as His words in QS at-TAUBAH [9]: 60.

Islamic view, which looks at the fact of poverty / poverty as the same case, both in Europe, the US and in Islamic countries. Even at any time, poverty is the same as its essence. Therefore, the mechanism and way of solving the problem of poverty in the view of Islam remains the same as its laws, does not change and does not differ from one country to another. Islam considers that poverty is a fact faced by humanity, both Muslim and non-Muslim. Islam views that the problem of poverty is the problem of not fulfilling primary needs as a whole. Islamic SHARI'A has determined the primary needs (which concern human existence) in the form of three things, namely clothing, food and shelter. Allah SWT. said:

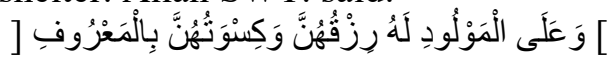

"The obligation of the father is to provide food and clothes to the mothers in a meaningful way" (Surah al-Baqarah [2]: 233).

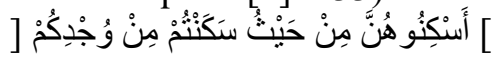

"Place them (wives) where you live, according to your ability" (Surah ATH-THALAAQ [65]: 6).

RASULULLAH saw. said:

"Remember, that their right to you is that you do good to them in (giving) clothes and food" (IBN MAJAH).

From the verses and hadiths above, it can be understood that three cases (namely clothing, food and shelter) are classified as basic needs, which are closely related to the existence of human existence and honor. If this (primary) basic need is not fulfilled, it can result in the destruction or decline (existence) of humanity. Therefore, Islam regards poverty as a threat that is usually exhaled by Satan, 
as the word of God Almighty. "Satan promises (scares) you with poverty" (QS AL-BAQARAH [2]: 268).

Thus, whoever and wherever they are, if someone cannot fulfill their basic needs, namely clothing, food and shelter, it can be classified as a group of people who are poor or poor. Therefore, every economic recovery program aimed at alleviating the poor must be addressed to those who belong to the group. Both the person has a job, but still cannot meet their basic needs in a meaningful way, namely poor people, or those who do not have jobs due to layoffs or other reasons, namely poor.

If the Islamic poverty benchmark is compared to other benchmarks, there will be a very striking difference. The benchmark of poverty in Islam has a much higher value than other benchmarks. Because, poor benchmarks in Islam include three aspects of meeting basic needs for human individuals, namely food, clothing and food. The other benchmarks generally only focus on meeting food needs alone.

Factors Affecting Poverty. Poor humans are not due to human nature, but there are causes that affect humans to be poor. Including the following:

1. Monopoly System

Monopoly and injustice in the distribution of staples in a number of regions is one of the factors of poor people. Poor people are targeted by consumers for the rich and the poor are the target of learning and abuse of consumer goods, even distribution of staples is not evenly distributed to the poor.

This has been explained in Al-Quran Surah AL-BAQARAH verse 143 which means "And likewise, we have made you Muslims a just and elect community so that you become a witness of human actions and that the Prophet Muhammad be a witness for your actions."

The paragraph above explains that greedy and arbitrary human actions in the distribution of basic commodities are the cause of poverty in a number of regions, including in the territory of Indonesia. The monopoly system causes misery in the community, because there is price competition on consumer goods and production. Monopoly occurs in real terms to take greater profits to the poor in general. Monopoly is clearly not justified by the AL-QURAN and AS-SUNNAH, because monopoly is troubling the general public. Monopoly is often carried out by large companies and rich people with the aim of taking greater profits, until eventually exploitation occurs to consumers.

Excessive attitude and luxurious lifestyle. Excessive and extravagant attitude in living life is an untrue attitude in Islam. Being arrogant and showing off wealth, as well as being lavish is an unethical act. This attitude often causes an imbalance between poor and rich. Usually wealth becomes a tool to discredit the poor. The Poor are always helpless when dealing with the rich, because wealth is always a trading tool and a tool for criminalizing the environment. Allah has warned people who are always arrogant and excessive in looking at property, making them behave TUQYAN, tyranny and making them oppose the teachings of Allah.

Al-Quran verse 34: 35 that is "And we did not send into a land a reminder, but those who live in luxury in the land said, surely we deny what you send to deliver it. And they say: we have more wealth and children than you and we will not be punished ".

Islam always encourages people to believe and behave well by following in the footsteps of the Messenger of ALLAH W Humility, courtesy, honesty is an attitude that is always upheld by Islam. Besides getting the forgiveness and grace of God, good behavior is also able to give blessings to the surrounding environment and the general public.

Riba and Interest. Acts and actions of RIBA are actions that are prohibited by Islam and are one of the causes of poverty in society. This is because usury is an act that benefits only one person and is detrimental to the other. RIBA himself took advantage of people who owe in the form of excess money, arbitrarily. This action makes poor people (have debt) get poorer, because they have to pay excess money.

Community Empowerment Economic Efforts. The UMMAH economic empowerment is basically an effort to optimize and improve the ability of people per person, group and society in a particular environment so that they have the ability to improve their quality of life independently, especially in 
their economic problems. The UMMAH economy in this case is also the economy of the people, because the essence of both is the same. Community economy is an economic system that involves all levels of society in the development process.

In the context of Indonesia, the concept of empowerment is considered an antithesis of the concept of development. The concept of development is more reflective of the presence of policy planning and implementation models that are top down, elitist and far from the values of justice, while empowerment is more bottom up (KUSNADI, 2006), prioritizing communication between the community and the government as policy makers. This aspirational attitude is interpreted as an effort to explore and find problems from the community itself. That is, it is the people who find their own problems and then provide alternative solutions to these problems.

Empowering the people, namely developing, self-sufficient, empowering and strengthening the bargaining position of the lower classes against the forces of emphasis in all fields and sectors of life (PRIJONO, 1996). The empowerment of coastal communities is expected to strengthen their capacity and autonomy in managing the potential of coastal, marine and small island coastal resource resources optimally and sustainably as a way to ensure the survival of current and future generations. Thus, improving the quality of life of coastal communities can be achieved, local socio-economic dynamics develop, and the potential of natural resources is guaranteed sustainability.

Actualization of Islamic Values in ISTIQOMAH Empowerment Community (2008) in its journal Islamic Community Development explains the existence of five in empowering people, among others:

1. Community empowerment efforts can be seen as laying down a social order in which human beings can fairly and openly do their business as a manifestation of their abilities and potential so that their needs (material and spiritual) can be fulfilled.

2. Community empowerment is not seen as a process of giving from parties who have something to those who do not have.

3. Community empowerment must be seen as a learning process for the community so that they can independently make efforts to improve the quality of life.

4. Community empowerment is not possible without full involvement by the community itself. Participation is not merely defined as presence but the contribution of the stages that must be passed by a work program in community empowerment.

5. Community empowerment is an effort of community involvement in a development program when the community itself does not have enough power or supplies.

The five derivative principles are actually a reflection of the actualization of the value of Islam in providing a view of life so that it leads to a life order that is empowered and prosperous. The key to success is the integration of the material and spiritual dimensions in social life.

Legal Basis for Islamic Economic Empowerment.

1. Al-Qur'an

a. Al-Qur'an of Allah SWT says in QS. AL-A'RÁF verse 10 that has placed humans on earth and has made their livelihood in the world. This verse relates to TAMKIN (empowerment) is that humans have been created by God on earth to try."Verily We have placed you all on the face of the earth and We have made for you on earth (the source) of livelihood. Very little are you grateful. "(QS. $A L-A^{\prime} R A ́ F$ (7): 10)

b. Al-Qur'an of Allah SWT says in QS. AL-BAQARAH verse 269, Allah created man on earth with all His goodness, and also gave understanding of knowledge to humans "Allah bestows Al HIKMAH (deep understanding of the QUR'AN and the SUNNAH) to whom He wills. and whoever is blessed with wisdom, he has truly been blessed with many gifts. and only people who can take lessons (from the word of God). "(Q.S Surah AL-BAQARAH (2): 269)

c. Al-Qur'an of Allah SWT says in QS. AL-HASYR verse 18: Humans by Allah SWT are given many gifts and understanding but that will always be given to people who always give their trust to Allah, namely those who pay attention to their deeds because they prepare themselves for the 
afterlife. "O ye who believe, fear Allah and let everyone pay attention to what he has done for tomorrow (hereafter); and fear Allah, Allah knows best what you do. "(Surah AL-HASYR (59): 18 d. Al-Qur'an of Allah SWT says in QS. AT-TAUBAH verse 105 explains that humans must work because humans work also cannot be separated from Allah's supervision. "And Say: Work for you, Then Allah and His Messenger and the believers will see your work, and you will returned to (Allah) who knows the unseen and the real, then proclaims to you what you have done. "(QS. ATTAUBAH (9): 105)

This legal basis, if associated with economic empowerment is Allah SWT gives humans a gift in the form of a source of livelihood and wisdom, namely understanding and intelligence so that people keep trusting and thanking Allah SWT. This is done by paying attention to what it does (management in life) and working by not violating the provisions of Allah SWT so that it will survive the world and the hereafter.

2. Hadith

The following hadiths explain to help and help the helpless people, namely the poor. Poor people are people who are powerless because they cannot eradicate their lives for the better. Therefore, the following hadith are related to the concept of empowerment. The hadiths relating to empowerment or TAMKIN are as follows:

a. A person who becomes a leader must provide eligibility to the one he leads and even provide what he uses. it is explained in the hadith below. "From $A B U D H A R$ RA, he said. The Messenger of Allah said, (NISAB) your brothers and sisters have made Allah under your hand. So, give them food like what you eat, and give them clothes like what you wear, and do not burden them with anything that can be burdensome them. And if you charge something to them, then help them. " (HR. IBN MAJAH)

b. In relation to economic empowerment, it is leaders who provide policies in the empowerment program so that they must provide policies according to the needs of the target community and the policy does not burden the people, it is explained in the hadith below. "From 'AISYAH RADIYALLAAHU' ANHU that the PROPHET SALLALLAAHU 'ALAIHI WA SALLAM said: O Allah whoever controls one of the affairs of my people then troubles them then give him trouble. " (HR. Muslim)

c. Economic empowerment can be realized if there is cooperation between one person and another. In this cooperation must be created a sense of togetherness, mutual love and trust. This reinforcement is listed in the following hadith: "From ANAS that the Prophet SALLALLAAHU 'ALAIHI WA SALLAM said:" For the sake of God whose soul is in His hand, not a servant (said) believes so that he loves his neighbor or his brother as he loves himself. " (MUTTAFAQ ALAIHI)

d. Economic empowerment is related to the problem of poverty, by helping poor people it will be rewarded and poverty criteria not only limited to lack of food, but shortcomings in meeting their needs. This is stated in the hadith of the Prophet Muhammad below: "From ABU HURAIRAH RA, that the Messenger of ALLĀH MISKIN said, the poor are not around asking others, then he receives a bite or two of bribes, or receives one or two dates. "Friends ask," Then what is meant by poor O RASULULLAH? "He replied, 'The person who does not have sufficient wealth, but the situation is unknown, so he is given alms, and he does not ask for something for others." (HR Muslim)

\section{Research Methodology}

The type of research used is qualitative research with a descriptive approach. The analytical tool used is a qualitative analysis of the MILES and HUBERMAN model (1984) which consists of data reduction, data display, and conclusion of drawing / verification that is carried out interactively and continues continuously until complete, so that the data reaches saturation.

As for the focus of this research are as follows: 
1) A description of how the Islamic perspectives community economic empowerment model in Islamic villages in SIKKA Regency to alleviate poverty.

2) A description of the solution to alleviating poverty according to the Al-Qur'an

\section{Result and Discussion}

Islamic Perspective Economic Empowerment Model in SIKKA-Flores District Islamic Village. 1. Mosque-Based Empowerment Model

In the context of language, the mosque is interpreted as a place of prostration to worship Allah Almighty. This meaning is then often textually understood that the mosque is only for prostration activities and is not permitted to carry out other activities. Whereas in the aspect of history, various activities of the Prophet Muhammad SAW always made mosques as media, both in the fields of economics, politics, DA'WAH and others.

The following is the data on the number of MOSQUES and MUSHOLLA in SIKKA Regency

Table 1. Number of Houses of Worship by District in SIKKA Regency Year 2018

\begin{tabular}{|c|l|c|c|c|}
\hline No & \multicolumn{1}{|c|}{ SUBDISTRICT } & MOSQUE & $\begin{array}{c}\text { SURAU/ } \\
\text { MUSHALLA }\end{array}$ & Total \\
\hline 1 & ALOK SUBDISTRICT & 7 & 1 & 8 \\
\hline 2 & $\begin{array}{l}\text { ALOK BARAT } \\
\text { SUBDISTRICT }\end{array}$ & 4 & 3 & 7 \\
\hline 3 & $\begin{array}{l}\text { ALOK } \\
\text { SUBDISTRICT }\end{array}$ & 11 & & 3 \\
\hline 4 & $\begin{array}{l}\text { MAGEPANDA } \\
\text { SUBDISTRICT }\end{array}$ & 3 & & 3 \\
\hline 5 & PAGA SUBDISTRICT & 3 & & 4 \\
\hline 6 & $\begin{array}{l}\text { KEWAPANTE } \\
\text { SUBDISTRICT }\end{array}$ & 1 & & 2 \\
\hline 7 & KANGAE SUBDISTRICT & 2 & & 2 \\
\hline 8 & WAIGETE SUBDISTRICT & 2 & & 41 \\
\hline 9 & $\begin{array}{l}\text { TALIBURA } \\
\text { SUBDISTRICT }\end{array}$ & 37 & 4 & \\
\hline \multicolumn{1}{|c|}{ Total } & & & \\
\hline
\end{tabular}

Source: SIKKA District Religion Office

The data above illustrates that the existence of the Muslim community in SIKKA-Flores Regency has such great potential of facilities and infrastructure such as the availability of 37 mosques and 4 SURAU / MUSHOLLA among the majority of the Catholic population. This shows that mosquebased economic empowerment has a great opportunity and is a potential that should continue to be developed in the context of poverty reduction in the SIKKA District community.

Indeed, this great potential is unfortunate if it is not maximally empowered and simply ignored, because this human resource is a very valuable social capital. The problem is the number of mosques and Muslims that can potentially be used as local strengths of SIKKA Regency, if managed professionally and proportionally. Furthermore, in the management and economic empowerment, an attitude of trust, honesty, transparency and accountability can be instilled in the community and God Almighty.

This economic empowerment model through mosques in SIKKA Regency can be done through:

a. Establishment of BAITUL MAAL WAT TAMWIL (BMT). BAITUL MAAL WAT TAMWIL (BMT) is a concept of the Institute of Financial Management Islam basing principles of its activities to the Islamic principles with the aim to practice the teachings of the Koran, on the principle of mutual help, eradicate poverty of the people, promote economic progress of micro, 
educate Muslims to work with good management, honesty and trustworthy., prosper the mosque to invite customers BMT to join the prayer in congregation in the mosque, cooperation, mutual help increase / venture between capable with the needy, educate customers diligently making notes of debt as well as honest and discipline in debt repayments, inviting Muslims to sincerely issue zakat, infaq, alms according to their ability.

From the objectives outlined above, BMT has 3 (three) spirits, namely the spirit of carrying out religious teachings (the dimension of ISLAMIC DA'WAH), business seeking profit in sharia (economic dimension), and building awareness of others (social dimension).

Products in the activities of BMT is an attempt to collect funds from the public in the form of deposits have some kind of business as follows: Deposits MUDHARABAH usual, saves MUDHARABAH Hajj, deposits of MUDHARABAH UMRAH, deposits of MUDHARABAH sacrifices, deposits of MUDHARABAH EID, deposits of MUDHARABAH WALIMAHAN, deposits of MUDHARABAH AQIQAH, deposits of MUDHARABAH housing. While BMT in an effort to channel funds to the community in the form of financing has some kind of business as follows: lease financing goods (AL-IJAROH), working capital financing (MURABAHAH), financing for the results (MUDHARABAH), financing partnership (MUSYARAKAH), investment financing (BA'I BI TSAMAN AJIL), financing policy (QHARDUL HASAN)

In the spirit of BMT is expected SIKKA can overcome the problems of poverty that plagued residents in the township of Islam, by increasing the dimensions of the propagation of Islam, improve the economic life of the various types of activities in the field of economic empowerment and increased concern for others by giving Zakat and SADAQAH INFAQ.

In addition to the BAITUL MAAL (fund) and BAITUL TAMWIL (business development), in carrying out the activities of BMT in the township Islam should also be included with the development activities on the environment around the mosque, especially the recipients of financing done formally and always tucked in with religious teachings.

People's economic institutions such as BMT will be an indicator of a paradigm shift in the Muslim community in SIKKA Regency, meaning that mosques are no longer taboo to be used by various other activities including economic empowerment of the community. On that basis, the existence of mosques that already have BMT is a potential that should continue to be developed towards empowerment, and economic strengthening of Muslim communities in SIKKA Regency.

b. Mosque-based Family Empowerment Post Program (POSDAYA). The SIKKA Regency Mosque Council can work with universities to conduct a Family Empowerment Post socialization (POSDAYA). Activities can also be carried out collaboratively, namely groups of independent lecturers or lecturers who collaborate with the mosque community or sub-groups, both structural and non-structural in mosque activities to collaborate to hold activities jointly developed in a participatory and empowering manner.

Mosques have many potentials, including lifelong education centers, as a place of deliberation, fostering a spirit of harmony, mutual cooperation, sincerity and discipline, fostering tolerance in the form of friendship through various activities in mosques such as prayer and so on.

Mosque-based POSDAYA which aims to create an independent, trustworthy and prosperous family carrying out activities including:

a. Revitalize or revitalize activities in the mosque, not limited to age in order to become more alive in various activities in the mosque.

b. Increasing institutional capacity of mosques.

c. Increasing the capacity of human resources, including carrying out various skills activities through various activities carried out by mosque administrators.

d. Preserve the existence of mosques through various activities carried out by the younger generation.

POSDAYA activities are ranging from toddlers to the elderly, including disabled people, with five activities, namely religious, education, entrepreneurship, environmental and health development, 
which can be implemented gradually in each field of activities. The POSDAYA program in the economic field that can alleviate poverty is a sharia-based entrepreneurship program.

POSDAYA activities can be carried out with activities such as: Establishing POSDAYA in Islamic neighborhoods and providing training based on local wisdom such as fish processing training, bridal makeup training, handicraft making training for example using local ingredients (palm leaves, woven sarongs ) or use waste recycling, salt-making training, Catfish Farming Training and Post-harvest Product Processing, Mosque-based BAITUL MAAL Sub Training etc.

It is hoped that with these activities the residents of the Islamic village will motivate them to have an entrepreneurial spirit as the Prophet Muhammad SAW has done. Not many know the figure of the Prophet Muhammad as an entrepreneur. In fact, in his work as an entrepreneur, the Messenger of Allah successfully proved that to start a business one does not have to have money first. History has proven that in a young age, the Messenger of Allah has shown his persistence in going into the business world of "selling services" pastoring livestock of rich people in MAKKAH. Furthermore, his business career skyrocketed because he successfully carried out the concept of "Making Money Without Money" ("Making Money Without Money") with a strong "trustworthy business mentality and skills". Personality The Messenger of Allah was able to make the rich people of MAKKAH believe in the Messenger of Allah to manage their business. The ethos of entrepreneurship is something inherent in Islam. Islam is the religion of merchants, was born in a trading city, and spread throughout the world by merchants. Entrepreneurship is one of the great super lessons that can be learned from the life journey of the Prophet. History has noted that besides being the Messenger of Allah, the figure of Muhammad Saw. is a successful entrepreneur thanks to his business skills and trustworthy personality.

Mosque-based POSDAYA activities in SIKKA can be carried out jointly by the stakeholders in each village, for example the sub district head, the village head, mosque TAKMIR management, young generation, service / agency and certainly not leaving the community as the main actors in the activities Mosque-based POSDAYA.

2. Mosque Micro Loan Program (PMM)

This program is carried out in order to empower small (micro) entrepreneurs in Islamic villages to keep running and still exist and can even grow in their business amid the current competition and economic crisis. The mosque has a responsibility to educate and help the surrounding community to achieve maximum potential so that the community's resilience is formed which is beneficial to themselves and their environment.

In SIKKA District, the PMM program funds can be distributed in the form of loans to micro businesses located around the mosque such as fish traders, vegetable / fruit traders, food / drinks, staple goods traders and clothing and salon traders. The funds are obtained from donors by not using collateral (collateral) and based on sharia principles. Therefore, the loaned money must be returned in a timely manner so that funds can be rotated for other prospective borrowers.

\section{Conclusion}

The community economic empowerment model in an effort to alleviate poverty in WURING Village (Kampong Islam) SIKKA District, can adopt a model of mosque-based community economic empowerment programs, among others by establishing BAITUL MAAL WAT TAMWIL (BMT), Community Empowerment Post programs (POSDAYA), and Programs Mosque Micro Loan (PMM). This is an effort to help the people in the coastal areas who are categorized as poor, in order to further activate their economy.

\section{References}

Abdul MANAN, 1997, Islamic Economic Theory and Practice, Yogyakarta: PT DHANA BAKTI 
Abad BADRUZAMAN. 2007. The Theology of the Oppressed (Thematic Study of MUSTADH'AFIN'S Verses with Indonesian-Indonesian Approach), Yogyakarta: PUSTAKA PELAJAR.

Al Qur'an. (2010) Al-Qur'an TAJWEED and its Translation Equipped with ASBABUN NUZUL and HADITH SAHIH by the Ministry of Religion. Bandung, SYGMA EXAMEDIA ARKANLEEMA

Al-Quran Translate, 1991, Indonesian Ministry of Religion Abdurrahman, Encyclopedia of Economics, Finance and Trade, Jakarta: PT PRANDAYA PRAMITA

Harry HIKMAH, 2006, Community Empowerment Strategy, HUMANIORA UTAMA, Bandung.

KUSNADI. 2006, Philosophy of Coastal Community Empowerment, PENERBIT HUMANIORA, Bandung

NASTAGIN, 2006. Theory and Practice of Islamic Economics, Dana Bhakti WAKAF, Yogyakarta

NATA, ABUDDIN, DKK, 2008, AL QURAN Thematic Study of Social Construction, Bandung: ANGKASA RAYA

SUROYO, AL, DKK, 2006, Religion and Trust Brings Renewal. Jogjakarta: KANISIUS

HOQUE, NAZAMUL ,ABDULLAHIL MAMUN, ABDULLAH MOHAMMAD AHSHANUL MAMUN,(2014) Dynamics and traits of entrepreneurship: an Islamic approach, World Journal of Entrepreneurship, Management and Sustainable Development Vol. 10 No. 2, 2014 r Emerald Group Publishing Limited 2042-5961 DOI 10.1108/WJEMSD-04-2013-0027

ISTIQOMAH, SUPRIYANTINI. (2008) Empowerment in the Context of Islamic Community Development, Community Islamic. Community Development Journal. (Online), Volume 4, Number 1, June, page: 65-78. [Internet] Available from: http://iain.lampung.ac.id/ KOMUNITAS, JURNAL PENGEMBANGAN MASYARAKAT ISLAM.

ISTAN, Muhammad.(2017), Poverty Alleviation Through Community Economic Empowerment According to Islamic Perspective, Journal of Islamic Economics, Vol. 2, No. 1, 2017

RUSLAN, Ismail .(2012). Mosque-Based Community Economic Empowerment in Pontianak, Equator Journal - Journal Of Islamic Studies Volume 2 Number 1 March 2012

MATTHORIQ, SURYADI, MOCHAMAD ROZIKIN., Actualization of Islamic Values in Empowering Coastal Communities (Study of BAJULMATI COMMUNITY, GAJAHREJO, GEDANGAN DISTRICT, MALANG REGENCY), JURNAL ADMINISTRASI PUBLIK (JAP), Vol. 2, No. 3, Hal. 426-432

http://www.waspada.co.id/kemiskinan-jadi-masalah-terbesar-dunia, accessed on Monday, 25 Mei 2018

https://www.liputan6.com/bisnis/read/2256860/ The Poverty Reduction Level Government JOKOWI Strategy), accessed on Monday 25 Mei 2018

http://bapemas.jatimprov.go.id BAPEMAS (Community Empowerment Agency). (2011) Empowerment of Coastal Communities. [Internet] Available from: http://bapemas.jatimprov.go.id. (Accessed: 25 Mei 2018)

http://www.satujam.com/faktor-penyebab-kemiskinan/akses 15 Mei 2018 